\title{
Quality of care provided to the hospitalized child from the perspective of the companion
}

\author{
Qualidade da assistência à criança hospitalizada sob a ótica do acompanhante
}

Ylana Karine Fonseca de Medeiros ${ }^{1}$, Deborah Dinorah de Sá Mororó ${ }^{1}$, Juliana Teixeira Jales Menescal Pinto ${ }^{1}$, Nadja de Sá Pinto Dantas Rocha ${ }^{1}$, Gleiciane da Silva Fonseca ${ }^{1}$

Objective: to assess the companion's satisfaction with the quality of care provided to the hospitalized child. Methods: this is an evaluative study, carried out in a pediatric hospitalization unit of a University Hospital. Seventy companions of hospitalized children met the inclusion criteria and answered to the data collection instrument, composed of a form with socioeconomic information and another adapted to assess user satisfaction from the National Health Services Evaluation Program. Results: 45.7\% reported some delay in care during the child's hospitalization. There was satisfaction with the communication of information about the patient (88.6\%), visit time (75.7\%), cleaning of the environments (75.7\%), but $65.7 \%$ did not know where to make complaints or suggestions and $44.3 \%$ did not know the name of the professional who would see their child. Conclusion: in general, companions' satisfaction regarding the quality of care for hospitalized children was evidenced, and opportunities for improvement regarding users' rights were highlighted.

Descriptors: Health Evaluation; Quality of Health Care; Patient Satisfaction; Child Health.

Objetivo: avaliar a satisfação do acompanhante quanto à qualidade da assistência à criança hospitalizada. Métodos: estudo avaliativo, realizado numa unidade de internação pediátrica de um Hospital Universitário. Setenta acompanhantes de crianças internadas atenderam aos critérios de inclusão e responderam ao instrumento de coleta de dados, composto por um formulário com informações socioeconômicas e outro adaptado de satisfação dos usuários do Programa Nacional de Avaliação dos Serviços de Saúde. Resultados: $45,7 \%$ relataram relativa demora no atendimento durante a internação da criança. Houve satisfação com o repasse de informações sobre o paciente $(88,6 \%)$ e com o tempo de visita $(75,7 \%)$, limpeza dos ambientes (75,7\%), porém $65,7 \%$ não sabiam onde fazer reclamações ou sugestões e 44,3\% desconheciam o nome do profissional que atendera seu filho. Conclusão: no geral, evidenciou-se a satisfação dos acompanhantes quanto à qualidade da assistência à criança internada, destacando-se oportunidades de melhoria referentes aos direitos dos usuários.

Descritores: Avaliação em Saúde; Qualidade da Assistência à Saúde; Satisfação do Paciente; Saúde da Criança.

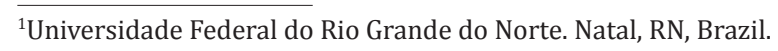




\section{Introduction}

Evaluative surveys of health actions and services, with the support of information derived from user satisfaction, are essential strategies for improving the quality of health care and consequent improvement of the health system ${ }^{(1-2)}$.

The National Health Services Assessment Program is an instrument used by the Brazilian Ministry of Health to encourage assessment of establishments and its general objective is to evaluate the efficiency, efficacy and effectiveness of structures, processes and results related to access, risk and user satisfaction towards public health services, seeking resolution and quality care in outpatient clinics and medium and high complexity hospitals ${ }^{(3)}$.

This process follows the benchmarks for quality definition, according to the Donabedian systemic model, which sets health care from the triad: structure - corresponding to the characteristics of resources, instruments, physical and organizational conditions employed in health care; process - referring to the description of activities, goods and health services provided; and outcome - related to the observation of changes in the health status of patients, as well as those aimed at the satisfaction of those involved in the care $^{(4)}$.

User satisfaction survey, as an element of outcome evaluation, covers distinct dimensions involving health care and encompasses from the professional-patient relationship to the quality of care and facilities of the service ${ }^{(3)}$. It allows, in addition to a feedback of the work process, users' political participation in health care and shared construction, as proposed by the humanization policy and by the organic laws of the Unified Health System.

Despite the recent increase in national research production on the quality of hospital care, most studies have targeted the adult population ${ }^{(5)}$. Thus, given the few studies in the pediatric area, it is necessary to publish such research to elucidate the reality of services and to supply the need for information about the health system - its mode of functioning, quality, effectiveness and safety - as well as to discuss and list problems to be solved.

In view of the particularities of the pediatric universe, parents and/or caregivers of hospitalized children are the mediators of the therapeutic relationship and, therefore, the best sources of information regarding satisfaction in child care ${ }^{(6)}$.

Therefore, in view of the need for a feedback on the quality of care provided in the Pediatric Hospitalization Unit of a University Hospital in northeastern Brazil and considering the assumption that structure and relational processes are directly associated to the companion's satisfaction about the care provided to the hospitalized patient, the following guiding question was raised: are the companions of hospitalized children satisfied with the quality of health care provided?

From this perspective, the present study aimed to evaluate the companion's satisfaction regarding the quality of care provided to the hospitalized child.

\section{Methods}

This is an evaluative study, carried out in the pediatric hospitalization unit of a General University Hospital in Natal, Rio Grande do Norte state, Brazil, which is a specialized referral unit with 30 beds available for medium and high complexity care of individuals aged zero to 15 years 11 months and 29 days.

The companions of hospitalized children participated in the study. The sample, which was non-probabilistic by convenience, consisted of 70 interviewees, selected from the eligibility criteria, which were: having been, for at least 24 hours, companion of a hospitalized child and being present at the hospitalization unit during the data collection period. Companions who did not stay full time with the child were 
excluded. Data collection was performed from July to September 2014 through a structured interview conducted at the pediatric unit.

A form with socioeconomic information (age, gender, race, marital status, education, occupation and family income) was used to characterize the companions as well as a user satisfaction survey form contained in the National Health Services Assessment Program $^{(3)}$, adapted to the population of this study and composed of closed questions.

Questions covered access and agility in care, welcoming, environment indicators, quality of health care, users' rights and their expectations regarding the health facility. In total, 15 questions were applied to the companions in the hospitalization service, in order to meet the objectives of the study.

After collection, the database was built and statistical analysis was performed using Statistical Product and Service Solutions, version 20.0 for Windows. In the descriptive analysis, the quantitative variables were presented by mean and standard deviation, while the categorical variables were presented by absolute and relative frequencies, in the form of tables.

In order to compare the differences in the proportion of socioeconomic variables and the satisfaction of the companions in relation to the outcome "Overall Expectation of Service", the Pearson's Chi-square test $\left(\mathrm{X}^{2}\right)$ was applied, with analysis of the adjusted and standardized residues to identify the best associations. Throughout the analysis, authors adopted a standard p-value of 0.05 and a confidence interval of $95.0 \%$.

In the analysis of some variables of the companion satisfaction survey instrument, it was necessary to group their options, without compromising data reliability, as in the case of satisfaction questions, in which four options (very satisfied, satisfied, dissatisfied and very dissatisfied) were grouped into two (satisfied and dissatisfied), and also in the questions on cleaning and comfort evaluation, in which five options (very good, good, fair, poor and very poor) were grouped into three (good, fair and poor). This way of grouping the data was chosen to facilitate information analysis and to avoid a consequent limitation of statistical tests.

The study complied with the formal requirements contained in the national and international regulatory standards for research involving human beings.

\section{Results}

Among the interviewees, seven (10.0\%) were men and 63 (90.0\%) were women, with a mean age of $32.2( \pm 9.2)$ years, mostly mothers $(88.9 \%)$, brown-colored (57.1\%) and married and/or in stable marital status (41.4\%). The predominant occupation was housewife $(47.1 \%)$, with basic/average level of education $(92.0 \%)$ and family income of one to two minimum wages $(55.7 \%)$ - considering that the minimum wage at the time of the study was $R \$ 724.00$ (equivalent to US\$315.00). The mean length of hospital stay of children was $6.6( \pm 4.5)$ days.

Regarding the time elapsed until provision of care, most of the companions (54.3\%) reported that the first care provided during hospitalization did not take long after admission. However, some answered that this care took a little time $(27.1 \%)$, took time (14.3\%) and took a very long time (3.0\%) to occur after admission, identifying a considerable delay through the grouping of such answers (45.7\%). Table 1 shows the description of some variables related to the companion's satisfaction regarding the care provided to the child.

When asked about the quality of care, most of respondents (97.1\%) answered that they were satisfied, reporting that the health team attended them with satisfactory courtesy (100.0\%), respect (98.6\%) and interest (95.7\%). In addition, a large part of the interviewees (95.7\%) stated that they felt confident about the team providing assistance. 
Table 1 - Companion satisfaction with care provided to hospitalized children

\begin{tabular}{lc}
\hline Variable & $\mathbf{n}(\mathbf{\%})$ \\
\hline Satisfaction with care (respect/courtesy/interest) & \\
Satisfied & $68(97.1)$ \\
Dissatisfied & $2(2.9)$ \\
Cleaning of environments & \\
Good & $53(75.7)$ \\
Fair & $16(22.9)$ \\
Poor & $1(1.4)$ \\
Food provided (children) & \\
Satisfied & $57(85.1)$ \\
Dissatisfied & $10(14.9)$ \\
Information about the patient & \\
Yes & $62(88.6)$ \\
No & $8(11.4)$ \\
Do you know the professional's name? & \\
Yes & $39(55.7)$ \\
No & $31(44.3)$ \\
Do you know where to make a complaint? & \\
Yes & $24(34.3)$ \\
No & $46(65.7)$ \\
Visit time & \\
It was as I expected & $53(75.7)$ \\
I did not receive a visit & $17(24.3)$ \\
Overall Expectation of Service & \\
Better than I expected & \\
Just as I expected & \\
\hline & \\
\hline
\end{tabular}

Regarding the environment, the predominant opinions characterized the pediatric hospitalization unit as clean, comfortable and well-signaled, since most of the companions (85.7\%) stated that the environment had signs that facilitated walking inside the hospital. Participants also classified cleaning (75.7\%) and the comfort of the rooms (88.6\%) as good.

When asked about the supply of clothes, nine participants said they chose not to use them to dress the children and therefore did not answer to such questions. Among those who answered, $41.0 \%$ reported lack of providing of clothes during the hospitalization of the child. The others reported receiving clean (59.0\%) and comfortable clothes (50.8), and $94.4 \%$ of them reported being satisfied.
On the food provided to the children, regarding the appearance of the food, quantity, temperature and the pre-established meal schedule, most participants (85.1\%) stated that they were satisfied. In addition, most of the companions reported having received guaranteed food $(92.9 \%)$ and satisfactory accommodations (95.7\%).

Regarding the duration of visit time, most of the companions (75.7\%) reported they were as they expected. The others reported not have received visits during hospitalization, so that none of the participants answered having had a shorter visit time than they expected.

Of all the interviewees, $88.6 \%$ reported having been informed about the health status of the hospitalized child, but $11.4 \%$ said they did not receive such information. In this context, only two questions have not fully reflected a good evaluation of the service. One of them refers to the identification of the professional who had provided assistance to the child, in which $44.3 \%$ of the interviewees reported not knowing the name of this professional.

The other question refers to the place where the user can make complaints or suggestions, in which $65.7 \%$ of the participants stated that they did not know about the existence of an environment intended for this purpose, even though the hospital had an ombudsman's office.

Most companions $(72.9 \%)$ revealed their expectations were exceeded regarding the service provided in the pediatric hospitalization unit of that university hospital. The opinions of the others diverged regarding having their expectations met, since some stated that the service was as they imagined (15.7\%), and some said they had no expectation whatsoever (11.9\%).

In the analysis of association between the outcome "overall expectation" of the service (recoded) and the socioeconomic and user satisfaction variables, statistical significance was found with the variables "information about the patient" and "visit time". Tables 2 and 3 present these results. 
Table 2 - Association between the variables information about the patient and overall expectation

\begin{tabular}{|c|c|c|c|c|}
\hline \multirow[b]{2}{*}{ Variable } & \multicolumn{2}{|c|}{ Overall expectation } & \multirow[b]{2}{*}{ Total } & \multirow[b]{2}{*}{$\mathbf{p}$} \\
\hline & $\begin{array}{l}\text { Better than } \\
\text { I expected } \mathbf{n} \\
\text { (\%) }\end{array}$ & $\begin{array}{c}\text { Just as I expected } \\
\text { or I did not have } \\
\text { expectations } \\
\text { n (\%) }\end{array}$ & & \\
\hline \multicolumn{5}{|c|}{ Information about the patient } \\
\hline Yes & $49(79.0)$ & $13(21.0)$ & $62(100.0)$ & \multirow{2}{*}{0.001} \\
\hline No & $2(25.0)$ & $6(75.0)$ & $8(100.0)$ & \\
\hline Total & $51(72.9)$ & $19(27.1)$ & $70(100.0)$ & \\
\hline
\end{tabular}

Table 3 - Association between the variables visit time and overall expectation

\begin{tabular}{lcccc}
\hline & \multicolumn{2}{c}{ Overall expectation } & & \\
\cline { 2 - 3 } Variable & $\begin{array}{c}\text { Better than I Just as I expected } \\
\text { expected }\end{array}$ & $\begin{array}{c}\text { or I did not have } \\
\text { expectations }\end{array}$ & Total & p \\
& $\mathbf{n}(\%)$ & $\mathbf{n}(\%)$ & \\
Visit time & $42(79.2)$ & $11(20.8)$ & $53(100.0)$ \\
It was as I expected & $9(52.9)$ & $8(47.1)$ & $17(100.0)$ \\
I did not receive a visit & $51(72.9)$ & $19(27.1)$ & $70(100.0)$ \\
Total & & & \\
\hline
\end{tabular}

Considering the analysis of the adjusted residues, for the variable "information about the patient", the association evidenced that those companions who received information about the child's health status (79.0\%) reported better evaluation of the service, as their overall expectation about the service was overcome, characterizing it as better than imagined. However, most of the companions who did not receive any information about the child's clinical condition (75.0\%) thought that the care provided was as they expected or they did not have expectations at all.

Regarding the variable "visit time", the analysis revealed that $79.2 \%$ thought that the visit time was in accordance with what they expected and provided a good evaluation of the service (as better than they expected).

\section{Discussion}

The study had limitations regarding the size of the sample, which was restricted to a single pediatric unit. However, there is potential for applying it for other services, using the same methodology as reference.

Most of the children's companions are their parents, and they are considered objects of care because they are experiencing, together with their children, the disease and hospitalization process ${ }^{(6)}$. In the study, most of the companions were mothers and housewives, which reinforces the idea that the hospitalization of a child interferes directly in the family dynamics, especially the mother's dynamics, since she becomes away from home to accompany the child during hospitalization $^{(7)}$.

Regarding the agility in care during hospitalization, despite few participants mentioned some delays, it is important that services become aware of the waiting time of all users and create strategies to improve agility in care, considering that a humanized care should prioritize reduced queues and waiting times, with increased access and welcoming and resolute reception ${ }^{(8)}$.

As for the relationship established between companions, children and the staff, the satisfaction of the interviewees raised reflection on the treatment developed with courtesy and respect by the health professionals, as it makes hospitalization a less painful and more tolerable experience for children and their companions $\mathbf{s}^{(6,9)}$.

Physical structure and comfort, also characterized by the companions as satisfactory, are fundamental aspects for the humanized care to the child and his/ her companion ${ }^{(6)}$. The concept of health environment is related to the treatment used in physical space, in the social, professional and interpersonal relations, which should provide the user with a warm, resolute and humanized care ${ }^{(10)}$. 
A systematic study of the literature has shown that health institutions have implemented strategies for the construction of warm and harmonious environments, in order to contribute to the improvement of care for hospitalized children, including the use of architecture as a way to promote well-being to children and their families ${ }^{(11)}$.

It is essential to provide companions with good conditions for staying with the children. Professionals involved in the care process should contribute to this purpose $^{(6)}$. In line with this, most participants reported having enjoyed satisfactory accommodations and food throughout their stay in the service.

Regarding access to information about the health status of the child, although most respondents were satisfied, not all participants had had this right assured. It should be noted that with the ease of acquiring knowledge through the internet, the health professional may lose credibility if the guidelines given are not consistent with those surveyed by the companions or when the professionals do not demonstrate having experience. Such conditions may result in a fragile relation between the caregiver and the user, lack of confidence in the professional, as well as non-adherence to the behaviors guided by him/her ${ }^{(12)}$.

In this sense, professionals involved in the care of the hospitalized child should pay special attention to communication and transmission of information to all parents and family members, in simple and clear language, preserving the ethical and legal principles regarding the rights of the companions, minimizing feelings of anguish and enabling positive outcomes ${ }^{(6)}$.

In addition, most caregivers were unaware of the name of the professional who assisted the child, which can be explained by the variety of professionals in the team and also by the turnover of undergraduates and residents, considering that that pediatric hospitalization unit is inserted in a school hospital that receives students from various health courses and offers medical and multidisciplinary residences.

Most of the interviewees also reported being unaware of the existence of an ombudsman sector.
These spaces enable social participation and contribute to the management and supervision of the quality of health services ${ }^{(13)}$. In this context, in order to guarantee this right to users, it is necessary to inform them about the existence of an ombudsman's office and provide other ways to receive their complaints in an accessible manner, guaranteeing the right to express their complaints, denunciations, needs and suggestions, either through ombudsmen, suggestion boxes or other existing mechanisms.

Given this, it is worth mentioning that the National Humanization Policy ensures that every user of the Unified Health System will be able to identify who are the professionals who take care of their health, ensuring that the health units will provide information to them, allowing the monitoring of people in their social network with free choice and the fulfillment of their rights ${ }^{(14)}$.

In addition, in order for the hospitalization process to be less traumatically experienced by children and their caregivers/relatives, it is essential that their needs be met by the service with the shared participation of children and families in health care ${ }^{(15)}$. The expanded and comprehensive conception of the health-disease process is relevant for the development of humanized actions in health care, since all action starts from a pre-existing health concept ${ }^{(16)}$. A view based on the comprehensiveness of the subjects requires qualified listening of their complaints.

Overall, the expectations of the companions regarding the service provided in the university hospital in question have been overcome. Data association showed that there was a direct effect in the overall expectation for those companions who has been informed about the health status of the child and also for those who were satisfied about the length of visit time, who said they had their expectations exceeded.

However, those companions who did not receive any information about the child's clinical condition said that the care provided by the service was as they expected or that they had no expectations.

Therefore, it is crucial to recognize the reality 
of health services and to reflect on the difficulties for the creation of strategies that allow solving the problems listed, guaranteeing a quality care.

In view of the above, this research data are expected to contribute to the improvement of child care, either in the said hospital or in other units, and also to raise awareness of health professionals and researchers about discussions and deepening regarding the quality of care to hospitalized child, considering the relevance of humanization and of the triad professional, child and family.

\section{Conclusion}

The present study evidenced the satisfaction of the companions as to the quality of care provided to hospitalized children regarding agility in care, relationship with and trust in the team, environment, food, clothing provided, length of visit time and conditions guaranteed to the companion, such as food and accommodation. However, there are opportunities for improvement regarding users' rights, identification of the professional that serves the child and lack of knowledge of the companions about the existence of an ombudsman office.

\section{Collaborations}

Medeiros YKF, Mororó DDS, Pinto JTJM and Rocha NSPD contributed to the conception, design and analysis of data. Medeiros YKF performed data collection. All authors contributed to the critical review, writing of the article and final approval of the version to be published.

\section{References}

1. Arruda CAM, Bosi MLM. Satisfação de usuários da atenção primária à saúde: um estudo qualitativo no Nordeste do Brasil. Interface. 2017; 21(61):32132. doi: http://dx.doi.org/10.1590/180757622015.0479
2. Molina KL, Moura GMSS. Patient satisfaction according to the form of hospital stay at a teaching hospital. Acta Paul Enferm. 2016; 29(1):1725. doi: http://dx.doi.org/10.1590/19820194201600004

3. Ministério da Saúde (BR). Secretaria-Executiva, Departamento de Regulação, Avaliação e Controle de Sistemas. PNASS: Programa Nacional de Avaliação de Serviços de Saúde. Brasília: Ministério da Saúde; 2015.

4. Gardner G, Gardner A, O'Connell J. Using the Donabedian to examine the quality and safety of nursing service innovation. J Clin Nurs. 2014; 23(2):145-55. doi: http://dx.doi.org/10.1111/ jocn.12146

5. Machado JP, Martins ACM, Martins MS. Avaliação da qualidade do cuidado hospitalar do Brasil: uma revisão sistemática. Cad Saúde Pública. 2013; 29(6):1063-82. doi: http://dx.doi.org/10.1590/ S0102-311X2013000600004

6. Torquato IM, Collet NC, Dantas MS, Jonas MF, Trigueiro JS, Nogueira MF. Assistência humanizada à criança hospitalizada: percepção do acompanhante. Rev Enferm UFPE on line [Internet]. 2013 [citado 2017 jul. 21]; 7(9):55419. Disponível em: https://periodicos.ufpe. $\mathrm{br} / \mathrm{revistas} /$ revistaenfermagem/article/ viewFile/13672/16561

7. Santos LF, Oliveira LMAC, Barbosa MA, Siqueira KM, Peixoto MKAV. Reflexos da hospitalização da criança na vida do familiar acompanhante. Rev Bras Enferm. 2013; 66(4):473-8. doi: http://dx.doi. org/10.1590/S0034-71672013000400002

8. Oliveira KKD, Amorim KKPS, Fernandes APNL, Monteiro AI. Impact of the implementation of patient engagement with risk classification for professional work of one urgent care unit. REME Rev Min Enferm. 2013; 17(1):157-64. doi: http:// dx.doi.org/10.5935/1415-2762.20130013

9. Barreto TSM, Sakamoto VTM, Magagnin JS, Coelho DF, Waterkemper R, Canabarro ST. Experience of parents of children with congenital heart disease: feelings and obstacles. Rev Rene. 2016; 17(1):12836. doi: http://dx.doi.org/10.15253/21756783.2016000100017 
10. Petean E, Costa ALRC, Ribeiro RLR. Repercussões da ambiência hospitalar na perspectiva dos trabalhadores de limpeza. Trab Educ Saúde. 2014; 12(3):615-35. doi: http://dx.doi. org/10.1590/1981-7746-sip00005

11. Ribeiro JP, Gomes GC, Thofehrn MB. Health facility environment as humanization strategy care in the pediatric unit: systematic review. Rev Esc Enferm USP. 2014; 48(3):527-36. doi: http://dx.doi. org/10.1590/S0080-623420140000300020

12. Carvalho S, Martins Filho J. Family relationships with pediatricians: the maternal views. Rev Paul Pediatr. 2016; 34(3):330-5. doi: http://dx.doi. org/10.1016/j.rppede.2016.03.015

13. Ministério da Saúde (BR). Secretaria de Gestão Estratégica e Participativa. Departamento de Ouvidoria-Geral do SUS. Guia de orientações básicas para implantação de ouvidorias do SUS. Brasília: Ministério da Saúde; 2013.
14. Ministério da Saúde (BR). PNH: Política Nacional de Humanização. Brasília: Ministério da Saúde; 2013.

15. Ribeiro JP, Gomes GC, Silva PA, Thofehrn MB, Oliveira AMN, Tarouco ACMB. Reflecting on the construction of caring in pediatrics. Rev Enferm UFPE on line [Internet]. 2016 [cited 2017 Jul 21]; 10(12):4672-9. Available from: http://www. revista.ufpe.br/revistaenfermagem/index.php/ revista/article/view/9079

16. Oliveira IC, Cutolo LRA. Humanização como expressão de integralidade. Mundo Saúde [Internet]. 2012 [citado 2017 jul. 21]; 36(3):5026. Disponível em: http://bvsms.saude.gov.br/bvs/ artigos/mundo_saude/humanizacao_expressao_ integralidade.pdf 